\title{
$\begin{array}{ll}\text { Research Square } & \text { Preprints are preliminary reports that have not undergone peer review. } \\ \text { They should not be considered conclusive, used to inform clinical practice, } \\ \text { or referenced by the media as validated information }\end{array}$
}

\section{Factors Related to Interprofessional Collaboration and Teamwork Climate in the Family Health Strategy}

\author{
Jader Vasconcelos ( $\square$ vasconcelosjd@gmail.com ) \\ Federal University of Mato Grosso do Sul \\ MARCIA Naomi Santos Higashijima \\ Federal University of Mato Grosso do Sul \\ Marcelo Viana Costa \\ Federal University of Rio Grande do Norte \\ Livia Fernandes Probst \\ Campinas State University \\ Mara Lisiane Moraes dos Santos \\ Federal University of Mato Grosso do Sul \\ Albert Schiaveto Souza \\ Federal University of Mato Grosso do Sul \\ Alessandro Diogo De Carli \\ Federal University of Mato Grosso do Sul
}

\section{Research Article}

Keywords: Working Environment, Primary Health Care, Family Health Strategy, Patient Care Team, Interprofessional Education, Interprofessional Relations, Cooperative Behavior, Health Workforce

Posted Date: April 5th, 2021

DOI: https://doi.org/10.21203/rs.3.rs-374493/v1

License: (9) This work is licensed under a Creative Commons Attribution 4.0 International License. Read Full License 


\section{Abstract}

Background: Working with an interprofessional focus is increasingly necessary, in view of the growing complexity of the population's health needs. This study aims to assess interprofessional collaboration and the teamwork climate in primary health care and determine whether there is a relationship between these two variables. In addition, the relationship of these two measures with the participants' sociodemographic variables was also analyzed.

Methods: The AITCS-II instrument was used to measure interprofessional collaboration, while to diagnose teamwork climate, the ECTE instrument was used, a version adapted to the SUS context of the Teamwork Climate Inventory instrument. These two instruments were applied online together with a questionnaire for the sociodemographic characterization of the 544 participants, who belonged to 97 Family Health Strategy teams in a Brazilian municipality.

Results: The study showed a strong correlation between interprofessional collaboration and teamwork climate. The studied sample had an unsatisfactory overall score regarding interprofessional collaboration. In addition, there was no relationship between teamwork climate or interprofessional collaboration and the participants' sociodemographic data; including the time of training and the presence or absence of postgraduate studies in public health or family health in the curriculum.

Conclusions: The study corroborates the literature, by indicating a correlation between teamwork and interprofessional collaboration, pointing to ECTE as another way to evaluate interprofessional work and the health work process. As for the sociodemographic variables, the results raise an alert towards the strengthening of interprofessional education actions, both during the training of new professionals and in the work process of professionals who are already working.

\section{Background}

Professionals from different centers of knowledge, working from an interprofessional perspective, increase the quality of health services provided to the population. Thus, the skills of team members and the sharing and management of cases optimize health practices and productivity in the work environment, with a consequent improvement in results and in the relationship with patient safety ${ }^{1}$.

The reorganization of the work process at the level of Primary Health Care (PHC) was based on teamwork, with the aim of offering the care that users need. In this sense, the medical-centered health care has been replaced by qualified multiprofessional care, which consists of different types of knowledge, capable of offering a broad scope of interventions to meet the population's health needs ${ }^{2}$.

Teamwork can be defined as the joint work of two or more professionals to achieve a common goal. Behavioral aspects such as coordination, communication, accountability and sharing of ideas are included in this work process ${ }^{3}$.

In this context, interprofessional collaboration can be defined as the partnership between a team of health professionals and their patients in a participatory, collaborative and coordinated approach to achieve shared decision-making regarding health care ${ }^{4}$. This can occur within a small team, between teams from the same service, or in the networking involving users and the community 5 .

There is evidence associating better teamwork climate values with better results in health care quality ${ }^{6-10}$ and greater user satisfaction ${ }^{8,11}$ in addition to providing strategic subsidies to support the development of collaboration within and between PHC teams ${ }^{12}$. In view of the importance of the theme for Primary Health Care and the scarcity of studies based on the Brazilian reality, the aim of this study was to analyze associated sociodemographic factors, interprofessional collaboration and the working climate in Family Health Strategy teams.

\section{Methods}

\section{Study design and sample}

This is an observational, cross-sectional and analytical study, carried out in Campo Grande, capital of the state of Mato Grosso do Sul (Brazil), from 2019 to 2020.

When defining the sample, the municipality had 146 Family Health Strategy (FHS) teams. However, only 125 of these teams were complete according to the Ministry of Health definition of a minimum team, which recommends that the team should consist of a doctor, a nurse and a nursing assistant or technician ${ }^{13}$, which is the inclusion criterion for sample definition; in addition to the aforementioned professional categories, when available, dental surgeons and dental assistants or technicians were also invited to participate in the study, as 
recommended by Agreli, Peduzzi and Bailey $(2017)^{12}$. In view of the singularity of the studied municipality, where most of the FHS units have professional social workers and pharmacists, these were also included in the sample.

For the sample calculation, a 95\% confidence interval and a $0.5 \%$ margin of error were taken into account, establishing a sample of 97 health teams $(\mathrm{N}=97)$. The participating teams were randomly stratified, respecting the geographic distribution and representativeness of each of the 7 health districts in this municipality (Anhanduizinho, Prosa, Segredo, Lagoa, Bandeira, Centro and Imbirussu), aiming at portraying a scenario as close as possible to reality.

To assess the team's participation, the criterion of a response rate of at least $40 \%$ was adopted in relation to the total number of professionals of the corresponding team. This strategy was also adopted by the authors of the team climate instrument ${ }^{14}$.

\section{Data collection and Variables}

Data collection was performed online using the Google Forms ${ }^{\circledR}$ platform. First, contact was made, via email and telephone, with the administrative managers of each participating health unit, to present the study proposal and request the submission of this information, along with the link to the online form, for the professional members of the selected teams. The participants' doubts related to the study were resolved via telephone contact and e-mail.

\section{Sociodemographic characteristics}

For the characterization of health professionals, the following information was collected: age, gender, education, specialization or continuing education course in Primary Health Care, time working in the team and time working in the institution.

\section{AITCS-II}

To measure interprofessional collaboration, the instrument ASSESSMENT OF INTERPROFESSIONAL TEAM COLLABORATION SCALE-II (AITCS-II) ${ }^{15}$ was used, after being translated, adapted and validated in Brazil by Bispo and Rossitt $(2018)^{16}$.

The AITCS-II consists of 3 dimensions, namely: partnership (8 items), cooperation (8 items) and coordination (7 items). Each item uses a 5point Likert scale (ranging from 1 = never to 5 = always).

\section{Teamwork Climate}

To assess teamwork climate, the Team Work Climate Scale (ECTE) instrument ${ }^{17}$, an adapted version, translated and validated into Portuguese from the Team Climate Inventory ( $\mathrm{TCl}$ ), was applied. The instrument consists of four factors: participation (frequency of interaction between team members, and how much they share ideas and information), support for new ideas (encouragement and practical support for new ideas), team objectives (information about the clarity and sharing of team objectives), task orientation (team commitment to the achievement of high standards of quality in the offered service) ${ }^{14}$.

Two of these factors use a Likert scale ranging from 1 to 5: participation (12 items) and support for new ideas (8 items). The other two factors use a Likert scale ranging from 1 to 7: team objectives (11 items) and task orientation (7 items).

\section{Data analysis}

After data collection, in order to assess teamwork climate and interprofessional collaboration, the total score was calculated using the four factors of ECTE and on the three factors of AITCS-II for each of the interviewees and then the averages of these scores were calculated per team. Subsequently to the calculation of the respective averages of each team, the total sample average was calculated for each factor of both instruments and the overall average per instrument (Teamwork Climate and Interprofessional Collaboration). This analysis used health teams as the study unit.

In the FHS Units in which there was less than one oral health team per health team, the data was replicated to all PHC teams belonging to this same unit, before calculating the team averages, as indicated by Agreli, Peduzzi and Bailey $(2017)^{12}$. The same procedure was carried out in the case of professionals from other categories who were not part of the basic configuration of a FHS team, such as social workers and pharmacists.

To characterize the participants that constitute the sample teams, the mean and standard deviation (SD) were calculated for data such as age, time since graduation, time at the institution or time working in the team; cases such as the numerical representativeness of positions or job functions, gender and the highest level of schooling, were presented as absolute numbers and percentages.

Page $3 / 12$ 
The evaluation of the linear correlation between the scores in the ECTE and in the AITCS-II domains, as well as their total score between the health teams was performed using Pearson's linear correlation test. The same test was used to assess the linear correlation between the scores in the ECTE or in the AITCS-II domains, as well as their total score, with time in the profession and time in the team, among the professionals participating in this study.

The comparison between genders, in relation to the scores in the ECTE and in the AITCS-II domains was performed using the Student's $t$ test. The same test was used in the comparison between professionals with and without specialization in Family Health or Public Health, in relation to the scores in the ECTE and the AITCS-II domains.

The comparison between different professionals, in relation to the scores in the ECTE and AITCS-II domains, was performed using the oneway ANOVA test, followed by the Tukey post-test, when necessary.

The other study results were presented as descriptive statistics or tables and graphs. Statistical analysis was performed using the SPSS statistical program, version 23.0, considering a significance level of $5 \%$.

\section{Results}

In total, 1,122 health professionals were invited to participate in the research. Of these, 544 (n) agreed to participate, totaling a final response rate of $48.4 \%$, related to $97 \mathrm{FHS}$ teams $(\mathrm{N})$. It was necessary to replace 6 health teams that comprised the initial sample, as the response rate was lower than the minimum rate (40\%) defined in the inclusion and exclusion criteria of this study. The data related to the participants' characteristics are shown in Table 1. 
Table 1

Sociodemographic characteristics of the professionals interviewed for this study.

\begin{tabular}{|c|c|}
\hline Domain & $\begin{array}{l}\text { Average } \pm \text { SDM or } \\
\% \text { (n) }\end{array}$ \\
\hline Age (22 to 67 years) & $39.5 \pm 8.95$ \\
\hline \multicolumn{2}{|l|}{ Sex } \\
\hline Female & $84.93(462)$ \\
\hline Male & $15.07(82)$ \\
\hline Time in the profession ( 0 to 41 years) & $11.11 \pm 8.29$ \\
\hline Time in the institution ( 0 to 35 years) & $9.00 \pm 9.59$ \\
\hline Time in the Unit (0 to 23 years) & $5.89 \pm 5.45$ \\
\hline Time in the team ( 0 to 23 years) & $4.90 \pm 5.03$ \\
\hline \multicolumn{2}{|l|}{ Office } \\
\hline $\mathrm{CHW}$ & $51.47(280)$ \\
\hline Dental surgeon & $11.21(61)$ \\
\hline Nurse & $10.48(57)$ \\
\hline Nursing assistant / technician & $9.56(52)$ \\
\hline Social Worker & $4.04(22)$ \\
\hline Oral Health Assistant / Technician & $7.90(43)$ \\
\hline Physician & $4.60(25)$ \\
\hline Pharmacist & $0.74(4)$ \\
\hline \multicolumn{2}{|l|}{ Highest level of schooling } \\
\hline Elementary School & $0.37(2)$ \\
\hline High school & $46.88(255)$ \\
\hline University/College education & $26.47(144)$ \\
\hline Postgraduate degree (residency / specialization / master's, Ph.D.) & $26.29(143)$ \\
\hline \multicolumn{2}{|l|}{ Specialization in Family Health / Public Health $(n=287)^{1}$} \\
\hline No & $73.87(212)$ \\
\hline Yes & $26.13(75)$ \\
\hline \multicolumn{2}{|l|}{1 Only professionals with higher education. } \\
\hline $\mathrm{SDM}=$ Standard deviation of the mean $\mathrm{CHW}=$ Community heal & orker. \\
\hline
\end{tabular}

With regard to training, professionals with a University/College or post-graduation level of schooling corresponded to $52.75 \%$ of the sample (287). Of these, $26.13 \%$ (75) had additional training in public health or family health.

The results regarding the teamwork climate and interprofessional collaboration, and the respective factors, as well as the general average of each of the two instruments are shown in Table 2. 
Table 2

Team Climate and Interprofessional Collaboration

\begin{tabular}{|ll|}
\hline Domain & $\begin{array}{l}\text { Average } \pm \text { SDM or } \\
\%(n)\end{array}$ \\
\hline Teamwork Climate & \\
\hline Team participation & $3.84 \pm 0.35$ \\
\hline Support for new ideas & $3.77 \pm 0.36$ \\
\hline Team goals & $5.76 \pm 0.51$ \\
\hline Task orientation & $5.42 \pm 0.69$ \\
\hline Total & $4.67 \pm 0.42$ \\
\hline Interprofessional collaboration & \\
\hline Partnership & $3.86 \pm 0.41$ \\
\hline Cooperation & $3.83 \pm 0.45$ \\
\hline Coordination & $3.43 \pm 0.45$ \\
\hline Total & $3.72 \pm 0.41$ \\
\hline
\end{tabular}

Overall average of the scores for each domain and total score in the Team Climate Inventory (TCI) and Interprofessional Collaboration scale and the respective standard deviation of the mean (SDM) for each item. There was a strong correlation between the results related to teamwork climate and interprofessional collaboration $(p<0.01$, Table 3 and Fig. 1$)$, considering the health teams as the study unit. This correlation was observed in all items, both from ECTE and AITCS-II.

Table 3

Linear correlation between Team Climate and Interprofessional Collaboration

\begin{tabular}{|c|c|c|c|c|}
\hline \multirow[t]{2}{*}{ TCI Domains } & \multicolumn{4}{|l|}{ IC Domains } \\
\hline & Partnership & Cooperation & Coordination & Total \\
\hline \multirow[t]{2}{*}{ Team participation } & $p<0.001$ & $p<0.001$ & $p<0.001$ & $p<0.001$ \\
\hline & $r=0.752$ & $r=0.764$ & $r=0.725$ & $r=0.799$ \\
\hline \multirow[t]{2}{*}{ Support for new ideas } & $p<0.001$ & $p<0.001$ & $p<0.001$ & $p<0.001$ \\
\hline & $r=0.755$ & $r=0.740$ & $r=0.700$ & $r=0.783$ \\
\hline \multirow[t]{2}{*}{ Team goals } & $p<0.001$ & $p<0.001$ & $p<0.001$ & $p<0.001$ \\
\hline & $r=0.769$ & $r=0.716$ & $r=0.685$ & $r=0.773$ \\
\hline \multirow[t]{2}{*}{ Task orientation } & $p<0.001$ & $p<0.001$ & $p<0.001$ & $p<0.001$ \\
\hline & $r=0.836$ & $r=0.840$ & $r=0.784$ & $r=0.877$ \\
\hline \multirow[t]{2}{*}{ Total } & $p<0.001$ & $p<0.001$ & $p<0.001$ & $p<0.001$ \\
\hline & $r=0.858$ & $r=0.842$ & $r=0.796$ & $r=0.890$ \\
\hline
\end{tabular}

Linear correlation between scores in the domains of the Team Climate Inventory (TCl) and in the domains of the Interprofessional Collaboration (IC) questionnaire, as well as their total score.P-value in Pearson's linear correlation test; $r=$ Pearson's linear correlation coefficient.

As for the position or job function in the team, the only significant difference $(p<0.05)$ observed was related to the item task orientation in the team work climate domain, in which the best result was observed for the professionals working as Social Workers and the worst for professionals working as Pharmacists (Table 4). 
Table 4

Comparison between different professionals, in relation to the scores of the TCI and those in the AITCS-II.

\begin{tabular}{|c|c|c|c|c|c|c|c|c|c|}
\hline \multirow[t]{2}{*}{ Domain } & \multicolumn{8}{|l|}{ Professional } & \multirow{2}{*}{$\begin{array}{l}\mathrm{p} \\
\text { value }\end{array}$} \\
\hline & $\begin{array}{l}\text { Community } \\
\text { Health } \\
\text { Agent }\end{array}$ & $\begin{array}{l}\text { Social } \\
\text { worker }\end{array}$ & $\begin{array}{l}\text { Nursing } \\
\text { assistant./technician }\end{array}$ & $\begin{array}{l}\text { Dental } \\
\text { health } \\
\text { assistant } \\
\text { / } \\
\text { technician }\end{array}$ & $\begin{array}{l}\text { Dental } \\
\text { surgeon }\end{array}$ & Nurse & Pharmacist & Physician & \\
\hline \multicolumn{10}{|c|}{ Teamwork Climate } \\
\hline $\begin{array}{l}\text { Team } \\
\text { participation }\end{array}$ & $3.83 \pm 0.64$ & $\begin{array}{l}3.95 \pm \\
0.59\end{array}$ & $3.84 \pm 0.73$ & $\begin{array}{l}3.97 \pm \\
0.59\end{array}$ & $\begin{array}{l}3.86 \pm \\
0.55\end{array}$ & $\begin{array}{l}3.81 \pm \\
0.62\end{array}$ & $3.39 \pm 0.62$ & $\begin{array}{l}3.91 \pm \\
0.86\end{array}$ & 0.239 \\
\hline $\begin{array}{l}\text { Support for } \\
\text { new ideas }\end{array}$ & $3.76 \pm 0.69$ & $\begin{array}{l}3.90 \pm \\
0.62\end{array}$ & $3.75 \pm 0.74$ & $\begin{array}{l}3.91 \pm \\
0.60\end{array}$ & $\begin{array}{l}3.74 \pm \\
0.64\end{array}$ & $\begin{array}{l}3.78 \pm \\
0.63\end{array}$ & $3.36 \pm 0.63$ & $\begin{array}{l}3.80 \pm \\
0.99\end{array}$ & 0.365 \\
\hline Team goals & $5.76 \pm 0.97$ & $\begin{array}{l}5.83 \pm \\
0.97\end{array}$ & $5.78 \pm 1.07$ & $\begin{array}{l}5.83 \pm \\
0.88\end{array}$ & $\begin{array}{l}5.78 \pm \\
0.97\end{array}$ & $\begin{array}{l}5.87 \pm \\
0.75\end{array}$ & $5.34 \pm 0.75$ & $\begin{array}{l}5.43 \pm \\
0.94\end{array}$ & 0.476 \\
\hline $\begin{array}{l}\text { Task } \\
\text { orientation }\end{array}$ & $\begin{array}{l}5.43 \pm \\
1.23 \mathrm{ab}\end{array}$ & $\begin{array}{l}5.94 \pm \\
1.10^{\mathrm{a}}\end{array}$ & $5.57 \pm 1.21 \mathrm{ab}$ & $\begin{array}{l}5.52 \pm \\
1.14 \mathrm{ab}\end{array}$ & $\begin{array}{l}5.34 \pm \\
1.14 \mathrm{ab}\end{array}$ & $\begin{array}{l}5.25 \pm \\
1.33 a b\end{array}$ & $\begin{array}{l}4.47 \pm \\
1.55 b\end{array}$ & $\begin{array}{l}5.19 \pm \\
1.51 \mathrm{ab}\end{array}$ & 0.012 \\
\hline Total & $4.67 \pm 0.74$ & $\begin{array}{l}4.85 \pm \\
0.63\end{array}$ & $4.70 \pm 0.79$ & $\begin{array}{l}4.78 \pm \\
0.64\end{array}$ & $\begin{array}{l}4.66 \pm \\
0.70\end{array}$ & $\begin{array}{l}4.67 \pm \\
0.66\end{array}$ & $4.15 \pm 0.81$ & $\begin{array}{l}4.56 \pm \\
0.93\end{array}$ & 0.180 \\
\hline \multicolumn{10}{|c|}{ Interprofessional collaboration } \\
\hline Partnership & $3.85 \pm 0.76$ & $\begin{array}{l}3.85 \pm \\
0.63\end{array}$ & $3.94 \pm 0.79$ & $\begin{array}{l}3.92 \pm \\
0.72\end{array}$ & $\begin{array}{l}3.83 \pm \\
0.73\end{array}$ & $\begin{array}{l}3.90 \pm \\
0.80\end{array}$ & $3.39 \pm 1.05$ & $\begin{array}{l}3.91 \pm \\
0.83\end{array}$ & 0.564 \\
\hline Cooperation & $3.82 \pm 0.79$ & $\begin{array}{l}3.88 \pm \\
0.69\end{array}$ & $3.91 \pm 0.80$ & $\begin{array}{l}3.93 \pm \\
0.70\end{array}$ & $\begin{array}{l}3.93 \pm \\
0.70\end{array}$ & $\begin{array}{l}3.84 \pm \\
0.76\end{array}$ & $3.82 \pm 0.90$ & $\begin{array}{l}3.65 \pm \\
0.86\end{array}$ & 0.958 \\
\hline Coordination & $3.41 \pm 0.82$ & $\begin{array}{l}3.63 \pm \\
0.78\end{array}$ & $3.63 \pm 0.85$ & $\begin{array}{l}3.43 \pm \\
0.89\end{array}$ & $\begin{array}{l}3.20 \pm \\
0.85\end{array}$ & $\begin{array}{l}3.48 \pm \\
0.90\end{array}$ & $3.04 \pm 0.72$ & $\begin{array}{l}3.54 \pm \\
1.04\end{array}$ & 0.202 \\
\hline Total & $3.71 \pm 0.70$ & $\begin{array}{l}3.79 \pm \\
0.61\end{array}$ & $3.84 \pm 0.68$ & $\begin{array}{l}3.78 \pm \\
0.69\end{array}$ & $\begin{array}{l}3.67 \pm \\
0.70\end{array}$ & $\begin{array}{l}3.74 \pm \\
0.77\end{array}$ & $3.37 \pm 0.86$ & $\begin{array}{l}3.79 \pm \\
0.86\end{array}$ & 0.596 \\
\hline
\end{tabular}

As for complementary training, having a specialization or not in public health or family health, did not imply a statistically significant difference $(p<0.05)$ in relation to the ECTE and AITCS-II scores (Table 5). 
The results of this study demonstrate the strong correlation between interprofessional collaboration and teamwork climate in all dimensions of both instruments used, reinforcing the importance of assessing teamwork climate in health services to promote more comprehensive, resolutive and higher-quality health care. This correlation was also observed by Ndibu et al. (2019) ${ }^{18}$ and suggested by Agreli, Peduzzi and Bailey (2017) ${ }^{12}$ in a study of mixed methods, in which the team climate seemed to be related to some aspects of interprofessional collaboration.

The version of the team work climate assessment instrument validated in the context of Brazilian $\mathrm{PHC}^{17}$ offers no recommendations on the stratification of the obtained numerical results. This makes it difficult to categorize the values obtained in the present study, whether they are satisfactory or not, which was also highlighted by Agreli, Peduzzi and Bailey (2017) ${ }^{12}$ in the only study carried out on the subject in Brazil to date, using health teams as the health care analysis unit.

As for interprofessional collaboration, considering the AITCS-II instrument, the literature states that values less than or equal to four, as observed in the present study, indicate unsatisfactory results ${ }^{19}$. This demonstrates there is still great difficulty working according to the precepts of interprofessional collaboration, even after decades dedicated to strengthening interprofessional work in FHS services. Thus, the complexity of the work processes in this context is emphasized, showing there is an urgent need for a permanent assessment of these issues, since it implies reflections in terms of micro and macropolitics of management and care.

Several years after the onset of the actions that proposed a new guiding axis in the process of training new professionals, aimed at comprehensive care and interprofessional work ${ }^{20-22}$, no significant difference was identified in the present study between professionals with less training time and the others in relation to the $\mathrm{Cl}$ and ECTE results. This finding demonstrates the challenge of consolidating the movement to change health education, which is permeated by the need to break with uniprofessional curricular structures, expanding the actions of interprofessional education. In this sense, redirections are still necessary to minimize these weaknesses and strengthen PHC, thus promoting quality care centered on the demands of the territory, based on a resolutive service.

Continuing education actions, such as the offer of postgraduate courses, have been subsidized by the Ministries of Health and Education, since the mid-1990s ${ }^{23}$. Unlike permanent education actions, those do not offer conditions for the true reflection on professional roles in the face of the reality of health services ${ }^{24}$. In the present study, no significant difference was observed in relation to the Cl and ECTE results, when comparing the results of professionals with or without specialization in public health or family health. This demonstrates that the challenge of transforming the work process and providing effective interprofessional work goes beyond the subsidy of continuing education actions, and that permanent and interprofessional education actions need to be constant in the routine of workers from the health sector.

From this perspective, the study results demonstrate formative weaknesses both in the most recent training at the undergraduate level, as well as in the lato sensu postgraduate program. Thus, strategic curricular reorientations are suggested in these two levels of training, so that this topic is contemplated in a longitudinal way as the training periods / modules advance.

Regarding the professionals' job function, only one correlation was observed between this domain and the task orientation dimension, demonstrating that, according to their job function in the team, the professionals have a different perception of their commitment to achieve high quality standards regarding the service offered by the team. In another study carried out in Brazil on teamwork climate (using individuals as a study unit) PERUZZO et al., (2019) ${ }^{25}$ observed a significant difference in all factors assessed by the ECTE questionnaire according to the participant's job function in the team. This divergence between the findings may have occurred because these authors used individuals (professionals) as the study unit, whereas the present study used health teams as the study unit, as recommended by Agreli, Peduzzi and Bailey (2017) ${ }^{12}$. Regarding interprofessional collaboration, there was no significant difference between the results when comparing the job function in the health team, which suggests the need for adjustments in the training and interprofessional education process in all professional categories, aiming to improve collaborative competences.

This study limitation is the use of a cross-sectional design, that is, the variables were measured at a single point of time, which suggests that the data cannot be used to infer cause and effect; in addition, the data cannot be generalized for all PHC contexts, considering that there are different configurations of it, characterized according to the local health system and the territory demands.

Thus, other studies, preferably with a mixed design, need to be carried out to better understand the possible relationship between work climate, professional collaboration and other factors that may influence the results of these two dimensions of the health work process.

The findings of this study are relevant because they provide support for health managers to adopt measures to improve team work climate and, consequently, provide more collaborative health care and, thus, better quality health care with better results. The results, regarding the

Page 9/12 
sociodemographic variables, raise an alert regarding the training of new professionals and the qualification actions of already trained professionals, showing the need to expand interprofessional education and the adequacy of the training process, aiming to train professionals and students to work increasingly more according to the principles of interprofessional collaboration.

\section{Conclusion}

It was concluded there was a correlation between teamwork climate and interprofessional collaboration, so that the better the working climate, the better the interprofessional collaboration in the corresponding team. As for the sociodemographic factors, only one correlation was observed between the professional's job function in the team and the factor participation in the team (related to teamwork climate). No other relationships were found between the sociodemographic characteristics and other teamwork climate factors or those related to interprofessional collaboration.

\section{Abbreviations}

PHC: Primary Health Care; FHS: Family Health Strategy; AITCS-II: Assessment of Interprofessional Team Collaboration Scale II; TCl: Team Climate Inventory; ECTE: Team Work Climate Scale; SD: Standard Deviation.

\section{Declarations}

\section{Ethics approval and consent to participate}

The protocols were carried out in accordance with the Human Research Ethics Committee (CEP) of Federal University of Mato Grosso do Sul (UFMS) guidelines and regulations. This study was approved by the Human Research Ethics Committee (CEP) of Federal University of Mato Grosso do Sul (UFMS) under the number. 11920919.4.0000.0021. Every participant subject provided an informed consent form.

\section{Consent for publication}

Not applicable

\section{Competing interests}

None.

\section{Availability of data and materials}

The datasets used and/or analysed during the current study are available from the corresponding author on reasonable request.

\section{Funding}

This study was financed in part by the Coordenação de Aperfeiçoamento de Pessoal de Nível Superior - Brasil (CAPES) - Finance Code 001.

\section{Acknowledgments}

This work was carried out with support from the Federal University of Mato Grosso do Sul - UFMS / MEC - Brazil

\section{Authors' contributions}

Conception and design of the research: JV, MNSH, ADC, LFB.

Acquisition of data: JV, ASS, MNSH, ADC.

Drafting the article: JV, ADC, MLMS, MVC, LFB, MNSH. 
Revision the article: JV, ADC, MNSH, MVC, LFB, ASS, MLMS.

All authors read and approved the final manuscript.

\section{References}

1. World Health Organization. Redes de profissões de saúde. Enfermagem e obstetrícia. Recursos humanos para a saúde. Marco para ação em educação interprofissional e prática colaborativa. Genebra, CH: RPSEORHS; 2010.

2. Silva MC. Adaptação trancultural e validação de instrumento de avaliação de trabalho em equipe: Team Climate Inventory no contexto da Atenção Primária à Saúde no Brasil. 2014. Dissertação (Mestrado em Fundamentos e Administração de Práticas do Gerenciamento em Enfermagem) - Escola de Enfermagem, Universidade de São Paulo, São Paulo, 2014. doi:10.11606/D.7.2014.tde-30102014165103. Acesso em: 2020-09-26.

3. Reeves S, Xyrichis A, Zwarenstein M. Teamwork, collaboration, coordination, and networking: Why we need to distinguish between different types of interprofessional practice. J Interprof Care. 2018, 32(1):1-3. doi: 10.1080/13561820.2017.1400150.

4. Orchard CA, Curran V, Kabene S. Creating a Culture for Interdisciplinary Collaborative Professional Practice. Med Educ Online. 2005;10(1):4387. doi:10.3402/meo.v10i.4387

5. Peduzzi M, Agreli HLF, Silva JAM, Souza HS. TRABALHO EM EQUIPE: UMA REVISITA AO CONCEITO E A SEUS DESDOBRAMENTOS NO TRABALHO INTERPROFISSIONAL. Trab. Educ. Saúde. 2020, 18(1). https://doi.org/10.1590/1981-7746-sol00246

6. Beaulieu MD, Dragieva N, Del Grande C, Dawson J, Haggerty JL, Barnsley J, et al. The team climate inventory as a measure of primary care teams' processes: validation of the French version. Healthc Policy.2014; 9(3):40-54.

7. Bower P, Campbell S, Bojke C, Sibbald B. Team structure, team climate and the quality of care in primary care: an observational study. Qual Saf Health Care. 12(4):273-279; 2003. doi:10.1136/qhc.12.4.273

8. Campbell SM, Hann M, Hacker J, Burns C, Oliver D, Thapar A, Mead N, et al. Identifying predictors of high quality care in English general practice: observational study. BMJ. 323(7316):784-787, 2001. doi:10.1136/bmj.323.7316.784

9. Mundt MP, Agneessens F, Tuan WJ, Zakletskaia LI, Kamnetz SA, Gilchrist VJ. Primary care team communication networks, team climate, quality of care, and medical costs for patients with diabetes: A cross-sectional study. Int J Nurs Stud. 2016;58:1-11. doi:10.1016/j.ijnurstu.2016.01.013

10. Poulton BC, West MA. The determinants of effectiveness in primary health care teams. J Interprof Care. 1999, 13(1):7-18, 1999. DOI: / 13561829909025531

11. Proudfoot J, Jayasinghe UW, Holton C, Grimm J, Bubner T, Amoroso C et al. Team climate for innovation: what difference does it make in general practice?. International journal for quality in health care. Int J Qual Health Care. 2007;19(3):164-169.

doi:10.1093/intqhc/mzm005

12. Agreli H. F.; Peduzzi M.; Bailey C. The relationship between team climate and interprofessional collaboration: Preliminary results of a mixed methods study. Journal of Interprofessional Care, v. 31, n. 2, p. 184-186, 2017.

13. Brasil. Portaria $n^{\circ}$ 2.436, de 21 de setembro de 2017. Aprova a Política Nacional de Atenção Básica (PNAB), estabelecendo a revisão de diretrizes para a organização da Atenção Básica, no âmbito do Sistema Único de Saúde (SUS). Diário Oficial da União 22 set, 2017.

14. Anderson NR, West MA. Measuring climate for work group innovation: development and validation of the team climate inventory. J. Organ. Behav.1998; 19 (3):235-58.

15. Orchard C, Pederson LL, Read E, Mahler C, Laschinger H. Assessment of Interprofessional Team Collaboration Scale (AITCS): Further Testing and Instrument Revision. J Contin Educ Health Prof. 2018;38(1):11-18. doi:10.1097/CEH.0000000000000193

16. Bispo EP de F, Rossit RAS. Processo de validação e adaptação transcultural do assessment of interprofessional team collaboration SCALE II (AITCS II). J Manag Prim Health Care. 2018 8(3). https://doi.org/10.14295/jmphc.v8i3.599

17. Silva MC, Peduzzi M, Sangaleti CT, Silva D, Agreli, HF, West MA, et al. Adaptação transcultural e validação da escala de clima do trabalho em equipe. Rev. de Saúde Pública. 2016; 50(52). https://dx.doi.org/10.1590/S1518-8787.2016050006484

18. Ndibu Muntu Keba Kebe N, Chiocchio F, Bamvita JM, Fleury MJ. Variables associated with interprofessional collaboration: The case of professionals working in Quebec local mental health service networks. J Interprof Care. 2019;33(1):76-84.

doi:10.1080/13561820.2018.1515191

19. Caruso R, Magon A, Dellafiore F, Griffini S, Milani L, Stievano A, et al. Italian version of the Assessment of Interprofessional Team Collaboration Scale II (I-AITCS II): a multiphase study of validity and reliability amongst healthcare providers. Med Lav. 109(4):316324, 2018. doi:10.23749/mdl.v109i4.7101

Page 11/12 
20. Feuerwerker LAM. Diretrizes curriculares e projetos pedagógicos: é tempo de ação!. Rev. bras. enferm. 56 (4): 351-352, 2003. Available in: http://www.scielo.br/scielo.php?script=sci_arttext\&pid=S003471672003000400006\&lng=en. https://doi.org/10.1590/S003471672003000400006.

21. Furlan, P. G, Campos IO, Meneses KVP, Ribeiro HM, Rodrigues LMM. A formação profissional de terapeutas ocupacionais e o curso de graduação da Universidade de Brasília, Faculdade de Ceilândia. Cad. Bras. Ter. Ocup. 22(1):109-119, 2014. DOI: https://doi.org/10.4322/cto.2014.012

22. Furlanetto DLC; Bastos MM, Silva Junior JWS, Pinho DLM. Reflections on the conceptual basis of the National Curriculum Guidelines for the health degree courses. Comun. ciênc. saúde; 25(2): 193-202; 2014.

23. Scherer MDA, Oliveira Cl, Carvalho WMES, Costa MP. Cursos de especialização em Saúde da Família: o que a formação pode mudar no trabalho?. Interface (Botucatu).2016, 20 (58), 691-702. https://doi.org/10.1590/1807-57622015.0020

24. Ribeiro ECO; Motta JIJ. Educação Permanente como estratégia na reorganização dos serviços de saúde. Divulg. Saúde Debate, 1996;12:39-44.

25. Peruzzo HE, Silva ES, Batista VC, Haddad MCFL, Peres AM, Marcon SS. Clima organizacional e trabalho em equipe na estratégia saúde da família. Rev. Bras. Enferm. 2019, 72(3):721-727.https://doi.org/10.1590/0034-7167-2017-0770.

\section{Figures}

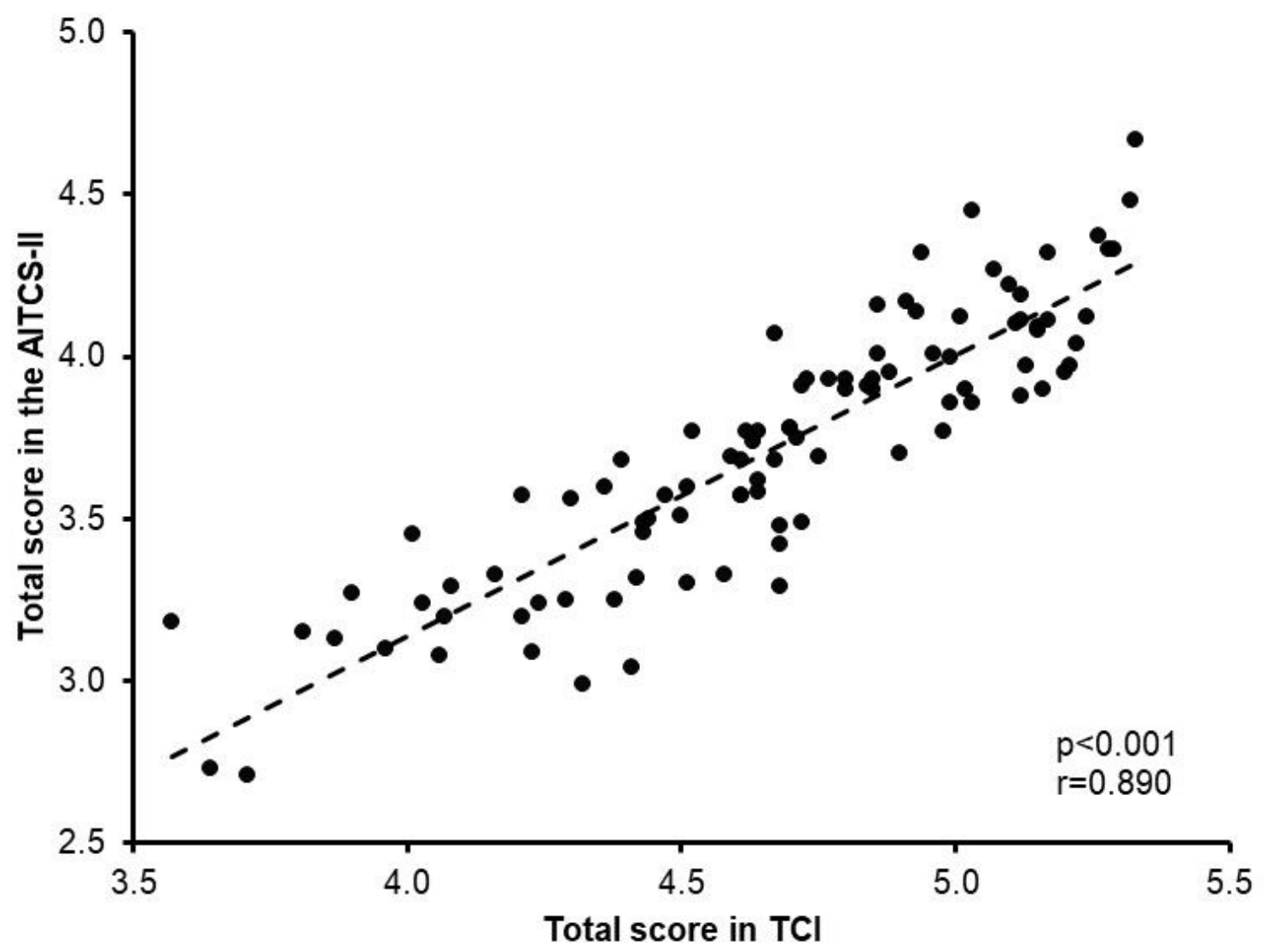

Figure 1

Linear correlation between the total score in the Team Climate Inventory (TCI) and that in the AITCS-II. 